\title{
Welcome New Associate Editor for Reflections in Family Medicine
}

\author{
Anne Victoria Neale, PhD, MPH and Juliann Binienda, PhD
}

(J Am Board Fam Med 2020;33:350.)

Juliann Binienda, PhD, Professor in the Department of Family Medicine and Public Health Sciences at Wayne State University, and new Associate Editor for JABFM

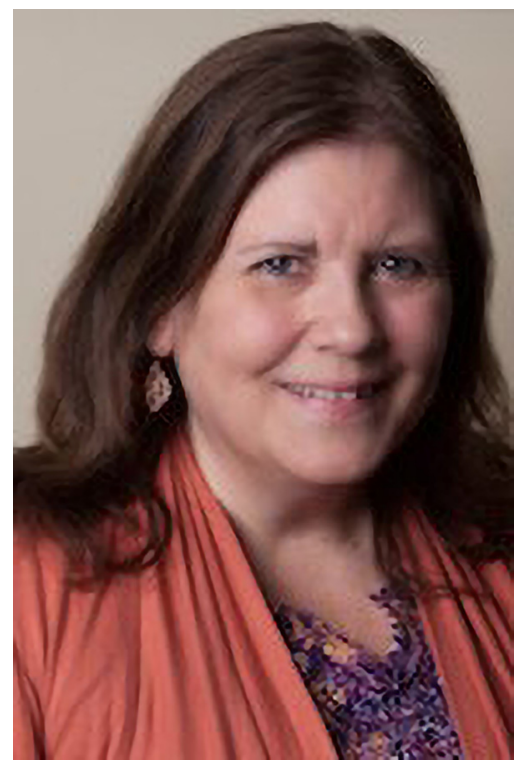

Fournal of the American Board of Family Medicine $(7 A B F M)$ welcomes Juliann Binienda, $\mathrm{PhD}$, as our new Associate Editor for our Reflections feature. Dr. Binienda is an Associate Professor at the Wayne State University with the Department of Family Medicine and Public Health Sciences. Her involvement in family medicine education spans more than 25 years and includes all levels of training. She has disseminated her scholarly work in several family medicine journals, including the 7ABFM.

Dr. Binienda is an experienced peer reviewer, having evaluated and critiqued dozens of manu- scripts; her reviews have been cited for their excellence, including their depth and breadth. She is a former Associate Editor for the STFM National Clerkship Curriculum. Dr. Binienda's editorship is guided by the following quote of the philosopher and writer Donald Schon, $\mathrm{PhD}$ :

"The reflective practitioner allows himself to experience surprise, puzzlement, or confusion in a situation which he finds uncertain or unique. $\mathrm{He}$ reflects on the phenomenon before him, and on the prior understandings which have been implicit in his behavior. He carries out an experiment which serves to generate both a new understanding of the phenomenon and a change in the situation."

\section{Seeking New Reflections}

Dr. Binienda is encouraging author submissions of narratives, poems, and reflective essays for the Reflections feature. She especially supports junior faculty, residents, and medical students in this endeavor, as reflective narratives can be a foray into scholarly writing for publication. Descriptive writing is also a mechanism that benefits well-being and improves patient and community health.

\section{Seeking New Peer Reviewers}

We seek new reviewers for these narratives, poems, and reflective essays. Updated author and reviewer guidelines are available for both types of reflections and are found at the bottom of the JABFM home page under "Authors \& Reviewers" (www.jabfm. org). Both authors and reviewers are encouraged to use these guidelines to improve their work.

To see this article online, please go to: bttp://jabfm.org/content/ 33/3/350.full. 